\title{
MODEL STOKASTIK PADA PERTUMBUHAN EKONOMI DI KABUPATEN KARO
}

\author{
Ferdinand Sinuhaji ${ }^{1}$, Juli Loisiana Butarbutar ${ }^{2)}$ \\ ${ }^{122)}$ Universitas Quality Berastagi \\ Email : sinuhajiferdinand@gmail.com
}

\begin{abstract}
ABSTRAK
Tujuan penelitian adalah menyusun model pertumbuhan ekonomi dikabupaten karo dengan stokastik sehingga dapat meramalkan jumlah pertumbuhan ekonomi kabupaten karo yang akan datang, Membandingkan nilai dugaan pertumbuhan ekonomi yang dibangun stokastik dengan model pertumbuhan ekonomi yang umum digunakan dalam teori ekonomi.

Metode penelitian dengan analisis data menggunakan model yang dibangun untuk diterapkan menganalisis pertumbuhan ekonomi dikabupaten karo dan menyusun model dengan asumsi matematika yang akan diterapkan kedalam model. Hasil penelitian adalah pendugaan PDRB Kabupaten Karo berdasarkan atas dasar harga konstan 2010 menurut pengeluaran kabupaten karo pada tahun 2019 yang akan datang adalah 14,22521 triliun Rupiah dan setahun kemudian atau yang belum diketahui adalah 14,72309 triliun Rupiah dan pendugaan jumlah pertumbuhan ekonomi dikabupaten karo pada tahun 2019 yang akan datang sebesar 4,95\%.

Setahun kemudian pendugaan pertumbuhan ekonomi kabupaten karo diduga mencapai 3,49\%. Kesimpulan nilai pendugaan pertumbuhan penduduk dari model yang dibuat pada tahun 2011, 2012, 2013, 2014, 2015, 2016, 2017, 2018 mendekati dengan nilai pertumbuhan penduduk yang sebenarnya dengan nilai MAPE sebesar 4,9590\%.
\end{abstract}

Kata Kunci : pertumbuhan ekonomi, model stokastik, analisis gerombol.

\section{ABSTRACT}

The purpose of this research is to compile a model of economic growth in Karo District with stochasticity so that it can predict the amount of economic growth in the future Karo District. The research method with data analysis uses a model that was built to be applied to analyze economic growth in Karo District and compose a model with mathematical assumptions that will be applied into the model.

The results of the study are the estimation of the Karo Regency GRDP based on the constant 2010 prices according to the forthcoming expenditure of karo district in 2019, which is 14.22521 trillion Rupiahs and a year later or unknown is 14.72309 trillion Rupiahs and the estimation of the amount of economic growth in the Karo district in 2019 to come at $4.95 \%$.

A year later the estimated economic growth of Karo district was estimated at $3.49 \%$. Conclusion The estimated value of population growth from the model made in 2011, 2012, 2013, 2014, 2015, 2016, 2017, 2018 is close to the actual population growth value with a MAPE value of $4.9590 \%$.

Keywords: economic growth, stochastic model, cluster analysis. 


\section{Pendahuluan}

Rahardjo (2013), Pertumbuhan ekonomi merupakan upaya peningkatan kapasitas produksi untuk mencapai penambahan output, yang diukur menggunakan Produk Domestik Broto (PDB) maupun Produk Regional Broto (PDRB) dalam suatu wilayah. Pada penelitian ini mengunakan faktor yang dapat mempengaruhi pertumbuhan ekonomi adalah nilai ekspor, pengeluaran pemerintah, tenaga kerja.

BPS Karo (2016), Di kabupaten karo laju pertumbuhan Produk Domestik Regional Broto (PDRB) terdata mengalami kenaikan dan penurunan, penurunan ini wajar dikarenakan aktivitas gunung sinabung yang mengalami erupsi (letusan) pada tanggal 27 Agustus 2010, gunung sinabung mengeluarkan asap dan abu vulkanis, lalu 2013, 2015, 2016, dan masih dirasakan sampai tahun 2018 sehingga PDRB nya mengalami penurunan terlihat bahwa tahun 2011 terdata sebesar 5,75\%, tahun 2012 terdata sebesar 5,09\%, tahun 2013 terdata sebesar 4,95\%, dan tahun 2016 mengalami kenaikan sebesar $5,17 \%$. BPS Karo (2018), Dari sisi pengeluaran, komponen pengeluaran konsumsi rumah tangga (PKRT) memberi kontribusi terbesar yaitu 52,67\%, kemudian komponen pembentukan modal tetap broto (PMTB) mempegaruhi terhadap pertumbuhan ekonomi adalah nilai ekspor, pengeluaran sebesar 31,36\% dan ekspor sebesar 26,83\%. Penelitian ini menggunakan PDRB atas dasar harga konstan 2010 menurut pengeluaran Kabupaten Karo sebagai indicator pertumbuhan ekonomi.

\section{Metode Penelitian}

Data yang digunakan dalam penelitian ini adalah agregat PRDB atas dasar konstan tahun 2010, yaitu jumlah produksi atau pendapatan atau pengeluaran yang dinilai atas dasar harga tetap (harga pada tahun dasar) yang digunakan dalam setahun. Perhitungan Produk Dosmestik Regional Broto pada penelitian ini secara konseptual menggunakan pendekatan pengeluaran. Di dalam penelitian ini digunakan data sekunder yang diambil dari Badan Pusat Statistik (BPS) di kabupaten karo. Data yang diambil adalah data tahun 2010 - 2017. Pembangunan model pertumbuhan ekonomi di kabupaten karo menggunakan asumsi - asumsi model pertumbuhan stokastik. Kemudian langkah selanjutnya melakukan analisis gerombol untuk mengetahui karakteristik di kabupaten karo. Analisis data yang dilakukan mengunakan model yang sudah dibuat untuk memperoleh nilai dugaan pertumbuhan ekonomi di kabupaten karo. Selain menggunakan data PDRB, faktorfaktor

yang

pemerintah, tenaga kerja yang akan disajikan menjadi variabel penelitian.

Tabel 1. Variabel Penelitian

\begin{tabular}{|c|c|c|c|}
\hline Tahun & Ekspor barang dan jasa & Pengeluaran Konsumsi pemerintah & Tenaga kerja \\
\hline 2013 & 3095,43 & 97760 & 206,048 \\
\hline 2014 & 3235,00 & 100815 & 208,839 \\
\hline 2015 & 3440,59 & 102867 & 228,207 \\
\hline 2016 & 3602,60 & 102415 & 210,956 \\
\hline 2017 & 3830,19 & 109171 & 218,038 \\
\hline
\end{tabular}

BPS Karo (2018), Variabel penelitian yang digunakan terdiri dari variabel dependen dan variabel independen yang ditunjukan oleh pada tabel 1. Defenisi operasional dari masing masing variabel dependent dan independent yang digunakan dalam penelitian sebagai berikut.
1. $\mathrm{Y}=\mathrm{PDRB}$ atas dasar konstan (variabel dependent)

2. $X_{1}=$ Nilai Ekspor Barang dan Jasa (variabel independent)

3. $\mathrm{X}_{2}=$ Pengeluaran konsumsi akhir Pemerintah (variabel independent) 
4. $\mathrm{X}_{3}=$ Tenaga Kerja (variabel independent)

Rachmawati dan Bekti (2013), Asumsi pembuatan model stokastik pertumbuhan ekonomi dikabupaten karo dengan menggunakan asumsi-asumsi dimana PDRB Kabaputen Karo digunakan untuk menghitung pertumbuhan ekonomi. Di mana pada penelitian ini adalah dengan mengganti ke dalam asumsi matematika.

b. dimana $\alpha$ PDRB atas dasar harga konstan 2010 menurut pengeluaran kabupaten Karo pada tahun $\alpha, \mu$ adalah PDRB atas dasar harga konstan 2010 menurut pengeluaran kabupaten Karo pada tahun $\alpha-1$, dan $\theta=$ $\theta_{1}-\theta_{2}$ adalah PDRB atas dasar harga konstan 2010 menurut pengeluaran kabupaten Karo pada tahun $\alpha\left(\theta_{1}\right)$ dan PDRB atas dasar harga konstan 2010 menurut pengeluaran kabupaten karo pada tahun $\left.\alpha-1\left(\theta_{2}\right)\right)$

c. Peubah acak $X_{i}$ yang banyaknya banyaknya peristiwa yang terjadi pada kelompok ke-i. banyaknya peristiwa yang terjadi pada kelompok yang berbeda adalah saling bebas dan berdistribusi peluang sama.

d. Parameter $\left\{\alpha_{n}=n \alpha+\theta\right\}$ dan $\left.\mu_{n}=n \mu\right\}$ adalah urutan bilangan positif yang menyatakan tingkat PDRB atas dasar harga konstan 2010 menurut pengeluaran kabupaten karo pada tahun $\alpha$, dan PDRB atas dasar harga konstan 2010 menurut pengeluaran kabupaten karpada tahun $\alpha-1$ dengan

a. Peluang untuk PDRB atas dasar harga konstan 2010 menurut pengeluaran kabupaten karo pada tahun $\alpha$,
Misalkan $\{X(t, t+h)$ adalah variabel acak yang menyatakan jumlah individu pada selang waktu $(t, t+h)$ :

a. $N(t, t+h) \quad$ menyatakan banyaknya kelompok pada waktu $(t, t+h)$, dan $N(t, t+$ $h)$ merupakan proses Poison dengan nilai harapan $(\alpha+\mu+$ $\theta) h$,

mengurangkan PDRB atas dasar harga konstan 2010 menurut pengeluaran kabupaten karo pada tahun $\alpha-1$ kemudian membagi dengan $100 \%$, dengan keadaan awal $M(0)=i$ dan $M(t)=E[X(t)] . \quad$ Untuk menentukan nilai $M(t+h)$ digunakan nilai harapan dengan syarat $X(t)$, sehingga diperoleh persamaaan : $M(t+h)=$ $E[X(X(t+h)]$

$=$

$E[E[X(t+h) \mid X(t))]]$.

Dengan demikian, dalam selang waktu $(t, t+h)$ kemungkinan peristiwa yang terjadi dalam proses PDRB atas dasar harga konstan 2010 menurut pengeluaran kabupaten Karo pada tahun $\alpha$ dan PDRB atas dasar harga konstan 2010 menurut pengeluaran kabupaten Karo pada tahun $\alpha-1$ dengan PDRB atas dasar harga konstan 2010 menurut pengeluaran kabupaten karo pada tahun $\alpha-1$ kemudian membagi dengan $100 \%$ adalah terjadi penaikan atau kenaikan pertumbuhan ekonomi, atau penurunan pertumbuhan ekonomi, atau tidak terjadi penaikan atau penurunan pertumbuhan ekonomi. Setiap kejadian terhadap ekonomi mempunyai peluang penaikan atau kenaikan sebagai berikut :

$$
\begin{aligned}
& \frac{1}{\sum_{i=1}^{N(t)} X i} E\left[X_{i}\right] X(t) \alpha h+o(h) \\
& \text { dengan } h \rightarrow 0 .
\end{aligned}
$$

b. Peluang untuk PDRB atas dasar harga konstan 2010 menurut pengeluaran kabupaten karo 


$$
\begin{aligned}
& \text { pada tahun } \alpha-1, \\
& \frac{1}{\sum_{i=1}^{N(t)} X i} E\left[X_{i}\right] X(t) \mu h+o(h) \\
& \text { dengan } h \rightarrow 0 .
\end{aligned}
$$

c. Peluang untuk PDRB atas dasar harga konstan kabupaten karo pada tahun $\alpha$ dikurangi PDRB atas dasar harga konstan 2010 menurut pengeluaran kabupaten karo pada tahun $\alpha-$

$$
1, \frac{1}{\sum_{i=1}^{N(t)} X i} E\left[X_{i}\right] X(t) \theta h+o(h)
$$
dengan $h \rightarrow 0$.

d. Peluang untuk tidak ada kenaikan dan penurunan PDRB atas dasar harga konstan 2010 menurut pengeluaran kabupaten karo pada tahun $\alpha$,

$$
X(t+h)=\left[\begin{array}{l}
\left(X(t)+\sum_{i=1}^{N(t)} X_{i} \text {, dengan peluang } \frac{1}{\sum_{i=1}^{N(t)} X i} E\left[X_{i}\right] X(t) \alpha+\theta\right] h+o(h) \\
\left(X(t)-\sum_{i=1}^{N(t)} X_{i}, \text { dengan peluang } \frac{1}{\sum_{i=1}^{N(t)} X i} E\left[X_{i}\right] X(t) \mu+\theta\right] h+o(h) \\
\left(X(t), \text { dengan peluang } 1-\frac{1}{\sum_{i=1}^{N(t)} X i} E\left[X_{i}\right] X(t)(\alpha+\mu)+\theta\right] h+o(h)
\end{array}\right]
$$

Johnson (2010), Analisis gerombol adalah analisis statistika peubah ganda yang digunakan apabila ada $n$ buah individu atau objek yang mempunyai $p$ peubah dan $n$ objek tersebut ingin dikelompokan ke dalam $k$ kelompok berdasarkan sifat-sifat yang diamati sehingga individu yang terletak dalam satu gerombol memiliki kemiripan sifat yang lebih besar dibandingkan dengan individu yang terletak dalam gerombol lain. Analisis gerombol merupakan salah satu teknik multivariat metode interdependensi (saling ketergantungan). Oleh karena itu, dalam analisis gerombol tidak ada pembedaan antara variabel bebas (independent variable) dan variabel terikat (dependent variable). Analisis gerombol digunakan untuk mengelompokkan data observasi yang hanya berdasarkan pada informasi yang ditemukan dalam data, di mana data tersebut harus menggambarkan observasi dan hubungannya. Tujuan dari analisis ini adalah observasi dalam satu kelompok dan PDRB atas dasar harga konstan $2010 \quad$ menurut pengeluaran kabupaten karo pada tahun $\alpha-1$ dengan mengurangkan PDRB atas dasar harga konstan 2010 menurut pengeluaran kabupaten karo pada tahun $\alpha-$ 1 kemudian membagi dengan $100 \%$.

$$
\begin{aligned}
& 1-\frac{1}{\sum_{i=1}^{N(t)} X i} E\left[X_{i}\right] X(t)(\alpha+ \\
& \mu)+\theta] h+o(h) \text { dengan } h \rightarrow \\
& 0 .
\end{aligned}
$$

Sehingga jika $X(t)$ diketahui, maka jumlah pertumbuhan ekonomi pada saat $t+h$ adalah : mirip satu sama lain dan berbeda dari observasi dalam kelompok lain. Tan (2010), Semakin besar kemiripan (homogenitas) dalam kelompok dan semakin besar perbedaan (heterogenitas) antar kelompok maka penggemborolan akan lebih baik dan lebih berbeda.

Pada analisis gerombol dibedakan menjadi metode hinarki (Hierarchical Clustering Method) dan metode non hinarki (Nonhierarchical Clustering Method). Metode hinarki digunakan apabila belum ada informasi jumlah gerombol yang dipilih. Metode analisis gerombol membutuhkan suatu ukuran ketakmiripan (jarak) yang didefinisikan untuk setiap pasang objek yang akan dikelompokkan. Johnson (2010) Jarak yang biasa digunakan dalam analisis penggerombolan diantaranya adalah Jarak Euclid.

Jarak Euclid paling sering digunakan untuk analisis gerombol. Jarak Euclid antara dua titik dapat diartikan dengan baik. Jarak yang digunakan adalah 
peubah kontinu. Jarak Euclid antara gerombol ke $-i$ dan ke- $j$ dari peubah $p$

$d(i, j)=$ jarak antara objek $i$ ke objek $j$

$\bar{x}_{t j}=$ nilai tengah pada peubah ke $t$ gerombol ke $j$

$\bar{x}_{i}=$ nilai tengah pada peubah ke $t$ gerombol ke $i$

$p=$ banyaknya peubah yang diamati

Everrit (2011), Motede Hinarki dibedakan menjadi dua metode pengelompokan, yaitu metode penggabungan dan metode pemecahan. Pada penelitian ini digunakan metode penggabungan untuk menganalisis gerombol. Proses penggabungan dua gerombol diulangi sampai diperoleh satu gerombol yang memuat sumua himpunan data. Hasil analisis gerombol dari metode ini disajikan dalam bentuk dendogram.

Juanda (2012), Analisis tren adalah suatu metode analisis statistika yang digunakan untuk melakukan suatu estimasi atau peramalan pada masa yang akan datang. Analisis tren terdapat tiga model yaitu tren linear, tren kuadratik, dan tren eksponensial.

Draper (2010), Tren linear dimana kecenderungan data dimana perubahannya berdasarkan waktu adalah konstan. Model yang digunakan adalah persamaaan tren linear:

$$
Y_{t}=a+b t
$$

Keterangan :

$Y_{t}=$ data time series pada periode $\mathrm{t}$

$t=$ waktu (Hari/bulan/tahun)

$a, b=$ konstanta

Nilai $a, b$ diperoleh didapat dari :

$$
b=\frac{\sum_{t=1}^{n} Y_{t} t-\sum_{t=1}^{n} Y_{t} \sum_{t=1}^{n} t}{\sum_{t=1}^{n} t^{2}-\left(\sum_{t=1}^{n} t\right)^{2}}
$$

Dan peubah diartikan sebagai $: d(i, j)=$ $\left[\sum_{t-1}^{p}\left(\bar{x}_{t j}-\bar{x}_{l}\right)^{2}\right]^{\frac{1}{2}}$

Dimana :

$$
a=\frac{\sum_{t=1}^{n} Y_{t}}{n}-b \frac{\sum_{t=1}^{n} t}{n}
$$

Tren kuadratik adalah kecenderungan data yang kurvanya berpola lengkungan. Secara matematika, tren kuadratik merupakan antara peubah tak bebas dengan $t$ dan $t^{2}$. Model persamaan kuadratik yaitu :

$$
Y_{t}=\beta_{0}+\beta_{1} t+\beta_{2} t^{2}
$$

Keterangan :

$Y_{t}=$ data time series pada periode $\mathrm{t}$

$t=$ waktu (Hari/bulan/tahun)

$\beta_{0}+\beta_{1} t+\beta_{2} t^{2}=$ konstanta

Tren eksponensial adalah kecenderungan perubahan data semakin lama semakin bertambah secara eksponensial. Terdapat dua model untuk tren eksponensial yaitu : Untuk peubah diskrit : $Y_{t}=\beta_{0}+\left(1+\beta_{1}\right)^{t}$ dan untuk peubah kontinu : $Y_{t}=\beta_{0}{ }^{e \beta_{1} t}$. Keterangan:

$Y_{t}=$ data time series pada periode $\mathrm{t}$

$t=$ waktu (Hari/bulan/tahun)

$\beta_{0}, \beta_{1}=$ Konstanta

Pemilihan model analisis tren untuk mendapatkan nilai peramalan terbaik didasarkan pada strandard error of the estimate (SSE) yang paling kecil. Pada penelitian ini ukuran akurasi hasil peramalan merupakan ukuran tentang tingkat perbedaan antara hasil peramalan dengan nilai yang sebenarnya. Pada penelitian ini ukuran kesalahan yang digunakan adalah MAPE (Mape Absolute Persentage Error), adapun persamaan nya :

$M A P E=\sum_{i}^{n} \frac{\left|P E_{i}\right|}{n}$, dengan $: P E=\left(\frac{x_{i}-F_{i}}{x_{i}}\right)$ 
Keterangan :

$x_{i}=$ data actual pada periode ke $i$

$F_{i}=$ nilai ramalan pada periode ke $i$

$n=$ banyaknya periode waktu.

\section{Hasil dan Pembahasan}

Dengan menggunakan asumsiasumsi yang ditelah dibangun dari persamaan (2.1) sehingga didapatkan model stokastik pertumbuhan ekonomi pada kabupaten karo: $\quad M_{t}=$ $\frac{\theta}{\alpha-\mu}\left[e^{E\left[X_{i}\right](\alpha-\mu) t}-1\right]+e i^{E\left[X_{i}\right](\alpha-\mu) t}$.

Bukti : $\quad E[X(t+h) \mid X(t)=[(X(t)+$ $\left.\left.\sum_{i=1}^{N(t)} X_{i}\right]\left[\frac{1}{\sum_{i=1}^{N(t)} X i} E\left[X_{i}\right] X(t) \alpha+\theta\right] h\right]+$ $[(X(t)-$

$\left.\left.\sum_{i=1}^{N(t)} X_{i}\right]\left[\frac{1}{\sum_{i=1}^{N(t)} X i} E\left[X_{i}\right] X(t) \mu\right] h\right] X(t)[1-$ $\left.\left.\frac{1}{\sum_{i=1}^{N(t)} X i} E\left[X_{i}\right] X(t)(\alpha+\mu)+\theta\right] h+o(h)\right]=$ $\left.\frac{X(t)}{\sum_{i=1}^{N(t)} X i} E\left[X_{i}\right] X(t) \alpha+\theta\right] h+$ $\left.\left.\frac{X(t)}{\sum_{i=1}^{N(t)} X i} E\left[X_{i}\right] X(t) \mu\right] h-E\left[X_{i}\right] X(t) \mu\right] h+$ $X(t)-\frac{X(t)}{\sum_{i=1}^{N(t) X i}} E\left[X_{i}\right][X(t)(\alpha+\mu)+\theta+$ $\left.o(h)=E\left[X_{i}\right] X(t) \alpha-X(t) \mu+\theta\right] h+$ $X(t)+o(h)$. Sehingga, $\quad M(t+h)=$ $E[E[X(t+h) \mid X(t)]]=E\left[E\left[x_{i}\right] X(t) \alpha-\right.$ $X(t) \mu+\theta] h+X(t) o(h)]=$ $E\left[E\left[x_{i}\right] X(t) \alpha-\mu(t) \mu+\theta\right] h+X(t)+$ $o(h)$

$$
\begin{aligned}
& M(t+h)=E\left[X_{i}\right][M(t)(\alpha-\mu)+\theta] h \\
& +M(t)+o(h) \\
& M(t+h)-M(t) \\
& =E\left[X_{i}\right][M(t)(\alpha-\mu) \\
& +\theta] h+o(h) \\
& \frac{M(t+h)-M(t)}{h} \\
& =E\left[X_{i}\right][M(t)(\alpha-\mu) \\
& +\theta]+\frac{o(h)}{h}
\end{aligned}
$$

Dengan menambahkan $h \rightarrow 0$ maka $\lim _{h \rightarrow 0} \frac{0(h)}{h}=0$
Jadi, $\quad \lim _{h \rightarrow 0} \frac{M(t+h)-M(t)}{h}=E\left[X_{i}\right][M(t)(\alpha-$

$\mu)+\theta$

$=E\left[X_{i}\right]\left[M(t)(\alpha-\mu)+E\left[X_{j}\right] \theta\right.$

Sehingga diperoleh persamaan berikut : $M^{\prime}(t)=E\left[X_{i}\right]\left[M(t)(\alpha-\mu)+E\left[X_{i}\right] \theta\right.$

(2.2)

Penyelesaian persamaan (1.8) dengan menggunakan persamaaan difrensial biasa [Forlow],

Misalkan $\quad h(t)=E\left[X_{i}\right][M(t)(\alpha-\mu)+$ $E\left[X_{j}\right] \theta$

Maka $h^{\prime}(t)=E\left[X_{i}\right]\left[M^{\prime}(t)(\alpha-\mu)\right.$.

Jadi persamaan (1.8) dapat ditulis sebagai berikut :

$h^{\prime}(t)=E\left[X_{i}\right]\left[M^{\prime}(t)(\alpha-\mu)\right.$

$\leftrightarrow \frac{h^{\prime}(t)}{E\left[X_{i}\right](\alpha-\mu)}=M^{\prime}(t)$

$\leftrightarrow \frac{h^{\prime}(t)}{E\left[X_{i}\right](\alpha-\mu)}=h(t)$

$\leftrightarrow \int \frac{h^{\prime}(t)}{h(t)} d t=\int E\left[X_{i}\right](\alpha-\mu) d t$

$\leftrightarrow \log h(t)]=\int E\left[X_{i}\right](\alpha-\mu) t+C$

$h(t)=e^{E\left[X_{i}\right](\alpha-\mu) t+C}=K e^{E\left[X_{j}\right](\alpha-\mu) t}$

Dari persamaan (2.3),

$h(t)=E\left[X_{i}\right]\left[M(t)(\alpha-\mu)+E\left[X_{i}\right] \theta\right.$

$K e^{E\left[X_{j}\right](\alpha-\mu) t}=E\left[X_{i}\right][M(t)(\alpha-\mu)+$

$E\left[X_{i}\right] \theta$

Dengan nilai awal $M(0)=i$, dimana $t=0$ sehingga diperoleh :

$K=E\left[X_{i}\right]\left[i(t)(\alpha-\mu)+E\left[X_{i}\right] \theta\right.$

$=E\left[X_{i}\right][i(t)(\alpha-\mu)+\theta$

Kemudian substitusikan nilai $\mathrm{K}$ kedalam persamaaan (2.4):

$$
\begin{aligned}
& E\left[X_{i}\right]\left[M(t)(\alpha-\mu)+E\left[X_{i}\right] \theta\right. \\
& =K e^{E\left[X_{j}\right](\alpha-\mu) t} \\
& \begin{array}{c}
\leftrightarrow E\left[X_{i}\right]\left[M(t)(\alpha-\mu)+E\left[X_{i}\right] \theta\right. \\
=E\left[X_{i}\right][i(t)(\alpha-\mu) \\
+e^{E\left[X_{j}\right](\alpha-\mu) t} \\
\leftrightarrow E\left[X_{i}\right][M(t)(\alpha-\mu) \\
=E\left[X_{i}\right][i(t)(\alpha-\mu) \\
+\theta] e^{E\left[X_{j}\right](\alpha-\mu) t}-E\left[X_{i}\right] \theta
\end{array}
\end{aligned}
$$

$M(t)$

$=\frac{E\left[X_{i}\right]\left[i(\alpha-\mu)+\theta e^{E\left[X_{i}\right](\alpha-\mu) t}-E\left[X_{i}\right] \theta\right.}{E\left[X_{i}\right](\alpha-\mu)}$

$=\left[i+\frac{\theta}{(\alpha-\mu)}\right] e^{E\left[X_{j}\right](\alpha-\mu) t}-\frac{\theta}{(\alpha-\mu)}$ 


$$
\begin{gathered}
=i e^{E\left[X_{j}\right](\alpha-\mu) t}+\frac{\theta}{(\alpha-\mu)} e^{E\left[X_{i}\right](\alpha-\mu) t} \\
-\frac{\theta}{(\alpha-\mu)} \\
=i e^{E\left[X_{i}\right](\alpha-\mu) t}+\frac{\theta}{(\alpha-\mu)} e^{E\left[X_{j}\right](\alpha-\mu) t} \\
-\frac{\theta}{(\alpha-\mu)} \\
\left.M(t)=\frac{\theta}{(\alpha-\mu)} e^{E\left[X_{i}\right](\alpha-\mu) t}-1\right]+ \\
i e^{E\left[X_{i}\right](\alpha-\mu) t} \quad(2.5)
\end{gathered}
$$

Sehingga diperoleh model stokastik pertumbuhan ekonomi pada kabupaten karo adalah :

$$
\begin{array}{r}
M_{t}=\frac{\theta}{\alpha-\mu}\left[e^{E\left[X_{i}\right](\alpha-\mu) t}-1\right] \\
+e i^{E\left[X_{i}\right](\alpha-\mu) t} .
\end{array}
$$

BPS Karo (2015), Pada penelitian ini dilakukan penggerombolan dengan metode penggabungan. Data yang digunakan adalah data PDRB atas dasar harga konstan 2010 menurut pengeluaran kabupaten karo 20102014 dan BPS Karo (2018), 2013-2017 dapat dilihat pada Tabel 2. Hasil penggerombolan dapat dilihat Tabel 3 dan gambar 1.

Tabel 2. Data PDRB atas dasar harga konstan 2010, menurut pengeluaran Kabupaten Karo 2010 - 2017

\begin{tabular}{|c|l|c|c|c|c|c|c|c|c|}
\hline $\begin{array}{c}\text { N } \\
\mathbf{0}\end{array}$ & $\begin{array}{c}\text { KomponenPen } \\
\text { geluaran } \\
(\mathbf{1})\end{array}$ & $\mathbf{2 0 1 0}$ & $\mathbf{2 0 1 1}$ & $\mathbf{2 0 1 2}$ & $\mathbf{2 0 1 3}$ & $\mathbf{2 0 1 4}$ & $\mathbf{2 0 1 5}$ & $\mathbf{2 0 1 6}$ & $\mathbf{2 0 1 7}$ \\
& \multicolumn{1}{|c|}{} & $\mathbf{( 3 )}$ & $\mathbf{( 4 )}$ & $\mathbf{( 5 )}$ & $\mathbf{( 6 )}$ & $\mathbf{( 7 )}$ & $\mathbf{( 8 )}$ & $\mathbf{( 9 )}$ \\
\hline 1 & Konsumsi & 485275 & 507217 & 531565 & 5567, & 5779 & 6123, & 6468, & 6810, \\
& RumahTangga & 5,22 & 2,40 & 1,23 & 18 & 9,68 & 45 & 40 & 77 \\
\hline 2 & Konsumsi & 165941, & 180153, & 190706 & 204,0 & 218,0 & 217,3 & 223,2 & 234,3 \\
& LNPRT & 46 & 67 &, 10 & 6 & 9 & 1 & 1 & 4 \\
\hline 3 & Konsumsi & 800163, & 861630, & 909181 & 977,6 & 1008, & 1028, & 1024, & 1091, \\
& Pemerintah & 06 & 25 &, 46 & 0 & 15 & 67 & 15 & 71 \\
\hline 4 & PMTB & 273194 & 288716 & 312209 & 3258, & 3441, & 3546, & 3713, & 3947, \\
& & 3,10 & 8,84 & 8,03 & 35 & 71 & 25 & 20 & 98 \\
\hline 5 & Perubahan & 568330, & 374698, & 663137 & 610,6 & 630,2 & 645,9 & 656,8 & 548,0 \\
& Inventori & 79 & 75 &, 18 & 2 & 3 & 9 & 1 & 2 \\
\hline 6 & Ekspor & 227523 & 264318 & 274733 & 3095, & 3235, & 3440, & 3602, & 3830, \\
& & 4,23 & 0,86 & 2,87 & 43 & 00 & 59 & 60 & 19 \\
\hline 7 & Impor & 216318 & 225755 & 268987 & 2947, & 3018, & 3121, & 3193, & 3317, \\
& & 8,74 & 3,55 & 7,37 & 26 & 47 & 33 & 52 & 15 \\
\hline 8 & Total PDRB & $\mathbf{9 2 3 , 1 1 7}$ & $\mathbf{9 7 6 , 1 4 5}$ & $\mathbf{1 0 , 2 5 8}$ & $\mathbf{1 0 , 7 6}$ & $\mathbf{1 1 , 3 1}$ & $\mathbf{1 1 , 8 8}$ & $\mathbf{1 2 , 4 9}$ & $\mathbf{1 3 , 1 4}$ \\
& & $\mathbf{9 , 1 3}$ & $\mathbf{1 , 2 1}$ & $\mathbf{2 2}$ & $\mathbf{5 9 9}$ & $\mathbf{4 3 9}$ & $\mathbf{0 9 3}$ & $\mathbf{4 8 7}$ & $\mathbf{5 8 5}$ \\
\hline
\end{tabular}

Berdasarkan tabel 2, terlihat bahwa sebahagian besar digunakan untuk memenuhi kebutuhan konsumsi akhir rumah tangga (PK-RT). Pengeluaran untuk aktivitas pembentukan modal tetap broto
(PMTB) juga mempunyai kontribusi besar. Data yang digunakan untuk mendapatkan hasil cluster dan hasil dendogram adalah PDRB atas dasar harga konstan 2010 menurut pengeluaran Kabupaten Karo per tahun 2010. 
Tabel 3. Cluster Membership

\begin{tabular}{|l|r|r|}
\hline Case & 3 Clusters & 2 Clusters \\
\hline 1:Konsumsi Rumah & 1 & 1 \\
Tangga & 2 & 2 \\
2:Konsumsi LNPRT & 2 & 2 \\
3:Konsumsi Pemerintah & 3 & 1 \\
4:Pembentukan modal & 2 & 2 \\
tetap Broto & 3 & 1 \\
5:Perubahan Inventori & 3 & 1 \\
6:Ekspor & 7:Impor & \\
\hline
\end{tabular}

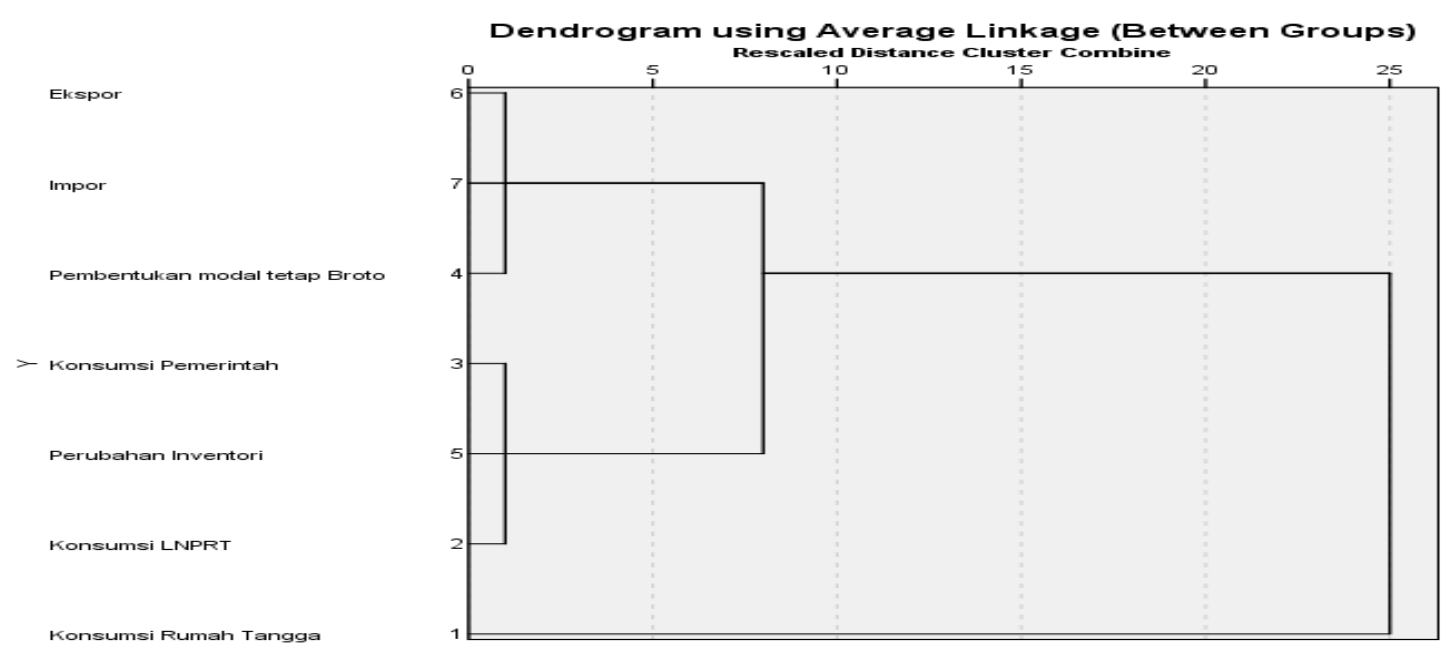

Gambar 1. Hasil dendogram dengan metode penggabungan

Berdasarkan hasil pada tabel 3 dan gambar 1 hasil dendogram dengan metode penggabungan diperoleh bahwa jika jaraknya ditentukan sebesar 25 maka setiap PDRB atas dasar harga konstan 2010 menurut pengeluaran Kabupaten Karo dapat digerombolkan menjadi 1 gerombol. Sehingga dapat diasumsikan bahwa setiap PDRB atas dasar harga konstan 2010 menurut pengeluaran Kabupaten Karo adalah Homogenitas (kesamaan) yang tinggi antar anggota dalam satu cluster (within-cluster).

Pada peramalan PDRB pada kabupaten karo yang akan datang diambil data pada masa lalu. Data masa lalu yang diukur secara periodik akan membentuk suatu deret waktu data (time series). Deret waktu adalah rangkaian data yang berupa nilai pengamatan terhadap variabel tunggal yang diukur selama kurun waktu tertentu. Perhitungan nilai ramalan PDRB pada kabupaten karo menggunakan analisis tren. Juanda (2012), Analisis tren ini terdapat 3 model yaitu tren linear, tren kuadratik, dan tren eksponensial.

BPS Karo (2018), Perhitungan peramalan pertumbuhan PDRB di kabupaten karo dengan menggunakan nilai parameter pada tabel 4 dengan melibatkan variabel penelitian.

Tabel 4. Nilai parameter pada PDRB Kabupaten Karo berdasarkan atas dasar harga konstan 2010 menurut pengeluaran kabupaten karo, dari tahun 2013-2017

\begin{tabular}{|c|c|c|c|c|}
\hline Tahun & PDRB & Ekspor barang dan jasa & $\begin{array}{c}\text { Pengeluaran konsumsi } \\
\text { pemerintah }\end{array}$ & $\begin{array}{c}\text { Tenaga } \\
\text { kerja }\end{array}$ \\
\hline
\end{tabular}




\begin{tabular}{|l|l|l|l|l|}
\hline 2013 & 10,76599 & 3095,43 & 97760 & 206,048 \\
\hline 2014 & 11,31439 & 3235,00 & 100815 & 208,839 \\
\hline 2015 & 11,88093 & 3440,59 & 102867 & 228,207 \\
\hline 2016 & 12,49487 & 3602,60 & 102415 & 210,956 \\
\hline 2017 & 13,14585 & 3830,19 & 109171 & 218,038 \\
\hline
\end{tabular}

Tabel 5. Model summary

\begin{tabular}{|c|r|r|r|}
\hline R & R Square & $\begin{array}{c}\text { Adjusted R } \\
\text { Square }\end{array}$ & $\begin{array}{c}\text { Std. Error of } \\
\text { the Estimate }\end{array}$ \\
\hline .929 & .864 & .818 & 40064.331 \\
\hline
\end{tabular}

The independent variable is variabel $\mathrm{x}$.

Tabel 6. Coefficients

\begin{tabular}{|c|c|c|c|c|c|}
\hline & \multicolumn{2}{|c|}{ Unstandardized Coefficients } & \multirow{2}{*}{$\begin{array}{c}\begin{array}{c}\text { Standardized } \\
\text { Coefficients }\end{array} \\
\text { Beta }\end{array}$} & \multirow[b]{2}{*}{$\mathrm{t}$} & \multirow[b]{2}{*}{ Sig. } \\
\hline & $\mathrm{B}$ & Std. Error & & & \\
\hline $\begin{array}{l}\text { variabel } \mathrm{x} \\
\text { (Constant) }\end{array}$ & $\begin{array}{r}20.895 \\
-951915.406\end{array}$ & $\begin{array}{r}4.792 \\
492031.998\end{array}$ & .929 & $\begin{array}{r}4.360 \\
-1.935\end{array}$ & $\begin{array}{l}.022 \\
.148\end{array}$ \\
\hline
\end{tabular}

Tabel 7. Model summary

\begin{tabular}{|c|r|r|r|}
\hline R & R Square & $\begin{array}{c}\text { Adjusted R } \\
\text { Square }\end{array}$ & $\begin{array}{c}\text { Std. Error of } \\
\text { the Estimate }\end{array}$ \\
\hline .945 & .892 & .785 & 43594.324 \\
\hline
\end{tabular}

The independent variable is variabel $\mathrm{x}$.

Tabel 8. Coefficients

\begin{tabular}{|c|c|c|c|c|c|}
\hline & \multicolumn{2}{|c|}{ Unstandardized Coefficients } & \multirow{2}{*}{$\begin{array}{c}\begin{array}{c}\text { Standardized } \\
\text { Coefficients }\end{array} \\
\text { Beta }\end{array}$} & \multirow[b]{2}{*}{$\mathrm{t}$} & \multirow[b]{2}{*}{ Sig. } \\
\hline & B & Std. Error & & & \\
\hline $\begin{array}{l}\text { variabel } \mathrm{x} \\
\text { variabel } \mathrm{x} * * \\
2 \\
(\text { Constant })\end{array}$ & $\begin{array}{r}223.936 \\
-.001 \\
- \\
11472221.408\end{array}$ & $\begin{array}{r}277.946 \\
.001 \\
14408794.873\end{array}$ & $\begin{array}{r}9.960 \\
-9.032\end{array}$ & $\begin{array}{r}.806 \\
-.731 \\
-.796\end{array}$ & $\begin{array}{l}.505 \\
.541 \\
.509\end{array}$ \\
\hline
\end{tabular}

Hasil output tren linear pada tabel 4 dan nilai coefficients pada tabel 5 dan hasil output tren Quadratic data PDRB Kabupaten Karo pada tabel 6 dan nilai coefficients pada tabel 7. Berdasarkan hasil yang didapatkan bahwa nilai SEE yang paling kecil adalah 40064.331 dibandingkan dengan model tren quadratic. Jadi model linear adalah model yang terbaik untuk mencari nilai peramalan PDRB atas dasar harga konstan 2010 menurut pengeluaran kabupaten Karo per tahun. Nilai koefisien tahun $\beta_{0}=20.895$ dan $\beta_{1}=-951915.406$. Dengan demikian dapat diambil rumusnya $\alpha_{t}=$ $20.895 e^{-951915.406 t}$ atau PDRB $=20.895$ $+(-951915.406)$. Berdasarkan tabel 5 koefisien regresi diatas dapat diketahui bahwa nilai sig $(0,022)<(0,05)$, berarti variabel independent (pengeluaran konsumsi pemerintah) berpengaruh terhadap variabel dependent (PDRB). Berdasarkan tabel 6 diketahui bahwa nilai $\mathrm{R}$ sebesar 0.929 yang mendekati angka 1 artinya adalah antara nilai variabel independent pada hal ini adalah yakni 
periode tahun memiliki hubungan yang erat dengan variabel dependent terikat PDRB dan nilai $\mathrm{R}$ Square sebesar 0.892 yang artinya variasi nilai PDRB dapat dijelaskan oleh periode tahun sebesar 0.892 atau $89,2 \%$ dan sisanya sebesar $10,8 \%$ dijelaskan oleh variabel lain diluar model.

Tabel 9. ANOVA

\begin{tabular}{|l|r|r|r|c|r|}
\hline & $\begin{array}{c}\text { Sum of } \\
\text { Squares }\end{array}$ & df & Mean Square & F & Sig. \\
\hline Regression & $\begin{array}{r}30516667535 . \\
199\end{array}$ & 1 & $\begin{array}{r}30516667535 . \\
199\end{array}$ & 19.012 & .022 \\
& $\begin{array}{r}1515451788.0 \\
01\end{array}$ & 3 & $\begin{array}{r}1605150596.0 \\
00\end{array}$ & & \\
Residual & $\begin{array}{r}35332119323 . \\
200\end{array}$ & 4 & & & \\
Total & & & & & \\
\hline
\end{tabular}

The independent variable is Indepent $\mathrm{x}$.

Berdasarkan pengujian ANOVA data PDRB kabupaten karo yang pada Tabel 8. Dengan melihat signifikansi dari PDRB. Nilai sig sebesar 0,022 yang berarti lebih kecil dari nilai alpha $(0,05)$. Dengan demikian dapat disimpulkan bahwa variabel independent (pengeluaran pemerintah) berpengaruh terhadap variabel dependent (PDRB).

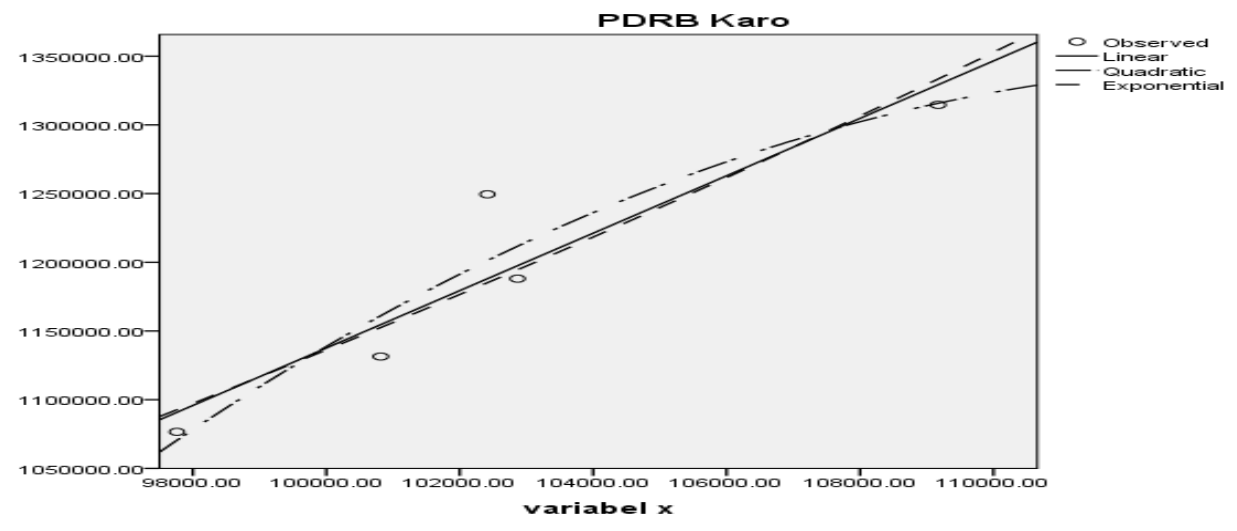

Gambar 2. Plot tren linear, quadratic dan eksponential

Membandingkan hasil model yang telah didapat dengan rumus pendugaan ramalan PDRB dengan menghitung dengan menggunakan rumus pertumbuhan secara (geometric) sebagai berikut: $\mathbf{P n}=\mathbf{P o}(\mathbf{1}+$ $\mathbf{r})^{\mathbf{n}}$, Dimana :

Pn $=$ Jumlah PDRB pada tahun $n$

Po $=$ Jumlah PDRB pada tahun dasar

$\mathrm{r}=$ Aturan pertumbuhan PDRB

$\mathrm{n}$ = Jangka waktu

Hasil perhitungan dengan rumus berikut adalah :

$$
\begin{aligned}
& P_{2018}=P_{2015}(1+r)^{n} \\
& 13,74417=11,88093(1+r)^{n} \\
& (1+r)^{n}=\frac{13,74417}{11,88093}
\end{aligned}
$$

$$
\begin{aligned}
& (1+r)^{n}=1,156826 \\
& 3 \log (1+3)=1,156826 \\
& \log (1+r)=\frac{0,063268}{4} \\
& \log (1+r)=0,015817 \\
& (1+r)=\text { anti } \log 0,015817 \\
& (1+r)=1,035 \\
& r=1,035-1 \\
& r=0,035 \\
& r=3,5 \% \\
& \text { Dengan demikian : } \\
& P_{2019}=P_{2018}(1+r)^{n} \\
& \quad=13,74417(1+0,035)^{1} \\
& \quad=13,74417(1,035)^{1} \\
& \quad=14,22521 \\
& P_{2020}=P_{2018}(1+r)^{n}
\end{aligned}
$$


$=13,74417(1+0,035)^{2}$

Dengan demikian dapat dihitung peramalan

$=13,744,17(1,035)^{2}$

PDRB pada tahun yang akan datang :

$=14,72309$

Tabel 10. Hasil Peramalan Jumlah PDRB Kabupaten Karo berdasarkan atas dasar harga konstan 2010 menurut pengeluaran kabupaten karo pada tahun yang akan datang

\begin{tabular}{|c|c|}
\hline Tahun & PDRB \\
\hline 2010 & 923,1179 \\
\hline 2011 & 976,1451 \\
\hline 2012 & 10,25822 \\
\hline 2013 & 10,76599 \\
\hline 2014 & 11,31439 \\
\hline 2015 & 11,88093 \\
\hline 2016 & 12,49487 \\
\hline 2017 & 13,14585 \\
\hline 2018 & 13,74417 \\
\hline 2019 & 14,22521 \\
\hline 2020 & 14,72309 \\
\hline
\end{tabular}

Sehingga peramalan jumlah PDRB berdasarkan atas dasar harga konstan 2010 menurut pengeluaran kabupaten karo untuk pada tahun 2019 dan 2020 yang belum diketahui adalah sebesar 14,22521 Triliun pada tahun 2019 dan sebesar 14,72309 Triliun pada tahun 2020.

Pendugaan pertumbuhan ekonomi pada Kabupaten Karo perhitungan nilai dugaan pertumbuhan ekonomi per tahun (periode) di kabupaten karo menggunakan model yang sudah dibangun yaitu persamaan (2.5). Dengan nilai parameterparameter yang dapat dilihat pada Tabel 14 . Setelah memperoleh nilai dugaan

Tabel 11. Nilai Parameter

\begin{tabular}{|c|c|}
\multicolumn{2}{|c|}{ Tabel 11. Nilai Parameter } \\
\hline Tahun & PDRB atas dasar harga konstan 2010 menurut pengeluaran kabupaten karo \\
\hline 2010 & 9231179 \\
\hline 2011 & 9761451 \\
\hline 2012 & 10,25822 \\
\hline 2013 & 10,76599 \\
\hline 2014 & 11,31439 \\
\hline 2015 & 11,88093 \\
\hline 2016 & 12,49487 \\
\hline 2017 & 13,14585 \\
\hline 2018 & 13,74417 \\
\hline
\end{tabular}

Tabel 12. Nilai dugaan pertumbuhan ekonomi pertumbuhan ekonomi pada kabupaten karo kemudian menghitung nilai kesalahan nilai dugaan dengan menggunakan MAPE (Mean Absolute Percentage Error). BPS Karo (2018), Pertumbuhan ekonomi di kabupaten karo cenderung berfluktuatif dan meningkat yakni 4,95\% pada tahun 2013 menjadi 5,21\% pada tahun 2017 .

BPS Karo (2018), Pertumbuhan ekonomi dikabupaten karo mengalami trend penaikan dalam setiap tahun. Terdata pada tahun 2010 - 2018 bahwa pertumbuhan ekonomi tertinggi pada tahun 2017 sebesar 5,21\%. 


\begin{tabular}{|c|c|c|c|}
\hline Tahun & $\begin{array}{c}\text { Pertumbuhan ekonomi } \\
\text { per tahun }\end{array}$ & $\begin{array}{c}\text { Nilai dugaan pertumbuhan } \\
\text { ekonomi per Tahun }\end{array}$ & Error \\
\hline 2011 & 5,74 & - & \\
\hline 2012 & 5,08 & - & $9,2929 \%$ \\
\hline 2013 & 4,95 & 5,41 & $1,5717 \%$ \\
\hline 2014 & 5,09 & 5,01 & $0,1996 \%$ \\
\hline 2015 & 5,01 & 5,02 & $2,3210 \%$ \\
\hline 2016 & 5,17 & 5,05 & $2,3032 \%$ \\
\hline 2017 & 5,21 & 5,09 & $14,0659 \%$ \\
\hline 2018 & 4,55 & 5,19 & $\mathbf{4 , 9 5 9 0} \%$ \\
\hline & \multicolumn{2}{|}{ MAPE } \\
\hline
\end{tabular}

Berdasarkan hasil pada tabel 11, bisa dilihat bahwa nilai dugaan pertumbuhan ekonomi per tahun pada tahun $2013,2014,2015$, 2016, 2017, 2018 dengan nilai $\alpha>1,(\alpha-$ 1) $<1, \theta<0$ dapat dikatakan cukup mendekati dengan nilai pertumbuhan ekonomi sebenarnya dengan nilai MAPE sebesar $4,9590 \%$.
Membandingkan nilai pertumbuhan tingkat ekonomi dengan nilai dugaan rumus pertumbuhan ekonomi secara umum. Dengan menggunakan rumus sebagai berikut : $G_{t}=\frac{P D R B_{t}-P D R B_{t-1}}{P D R B_{t-1}} \times 100 \%$

Sehingga didapat hasil perhitungan sebagai berikut :

Tabel 13. Pendugaan Pertumbuhan Ekonomi Kabupaten Karo

\begin{tabular}{|c|c|c|}
\hline Tahun & Proses Penghitungan & $\begin{array}{c}\text { Pertumbuhan } \\
\text { Ekonomi }\end{array}$ \\
\hline 2011 & $\{(\operatorname{Rp} 9761451,21-\operatorname{Rp} 9231179,13) / \operatorname{Rp} 9231179,13\} \times 100 \%$ & $5,74 \%$ \\
\hline 2012 & $\{(\operatorname{Rp} 1025822,50-\operatorname{Rp} 9761451,21) / \operatorname{Rp} 9761451,21\} \times 100 \%$ & $5,08 \%$ \\
\hline 2013 & $\{(\operatorname{Rp} 10,76599-\operatorname{Rp} 10,25822) / \operatorname{Rp} 10,25822\} \times 100 \%$ & $4,95 \%$ \\
\hline 2014 & $\{(\operatorname{Rp} 11,314,39-\operatorname{Rp} 10,765,99) / \operatorname{Rp} 10,765,99\} \times 100 \%$ & $5,09 \%$ \\
\hline 2015 & $\{(\operatorname{Rp} 11,88,093-\operatorname{Rp} 11,31,439) / \operatorname{Rp} 11,31439\} \times 100 \%$ & $5,01 \%$ \\
\hline 2016 & $\{(\mathrm{Rp} 12,49487-\mathrm{Rp} 11,88093) / \mathrm{Rp} 11,88,093\} \times 100 \%$ & $5,17 \%$ \\
\hline 2017 & $\{(\operatorname{Rp} 13,14,585-\operatorname{Rp} 12,49487) / \operatorname{Rp} 12,49487\} \times 100 \%$ & $5,21 \%$ \\
\hline 2018 & $\{(\operatorname{Rp} 13,74417-\operatorname{Rp} 13,14585) / \operatorname{Rp} 13,14585\} \times 100 \%$ & $4,55 \%$ \\
\hline 2019 & $\{(\operatorname{Rp} 14,22521-\operatorname{Rp} 13,74,417) / \operatorname{Rp} 13,74417\} \times 100 \%$ & $4,95 \%$ \\
\hline 2020 & $\{(\operatorname{Rp} 14,72309-\operatorname{Rp} 14,22521) / \operatorname{Rp} 14,22521\} \times 100 \%$ & $3,49 \%$ \\
\hline
\end{tabular}

Sehingga pendugaan pertumbuhan ekonomi kabupaten karo adalah pada tahun 2019 adalah $4,95 \%$, mengalami kenaikan $0,4 \%$ dibandingkan tahun 2018 dan peramalan pertumbuhan ekonomi tahun 2020 sebesar $3,5 \%$. 


\section{Kesimpulan}

Berdasarkan hasil penelitian nilai pendugaan pertumbuhan penduduk dari model yang disusun pada tahun pada tahun 2011, 2012, 2013, 2014, 2015, 2016, 2017, 2018 mendekati dengan nilai pertumbuhan penduduk yang sebenarnya dengan nilai MAPE sebesar 4,9590\%. Hasil penelitian analisis data menunjukan bahwa pendugaan PDRB Kabupaten Karo berdasarkan atas dasar harga konstan 2010 menurut

\section{Ucapan Terimakasih}

Peneliti mengucapkan terimakasih atas pendanaan penelitian dosen pemula kepada Direktorat Riset dan Pengabdian

\section{Daftar Pustaka}

Rahardjo Adisasmita, Teori-Teori Pembangunan Ekonomi, Pertumbuhan Ekonomi dan Pertumbuhan wilayah, cetakan pertama, Graha Ilmu, Yogyakarta,2013, hlm. 4.

BPS Kabupaten karo (2016). https://karokab.bps.go.id/

Badan Pusat Statistik (BPS) Kabupaten Karo. 2018. Kabupaten Karo Dalam Angka. Katalog 1102001.1211

Badan Pusat Statistik (BPS) Kabupaten Karo. 2015. Produk Domestik Regional Broto Kabupaten Karo Menurut Pengeluaran 2010-2014. Katalog 9302020.1211.

Johnson RA, Wichern DW. 2007. Aplied Multivariate Statistical Analysis. Ed Ke- 6. Amerika (US): Pearson Prentice Hall.

Tan P, Steinbach M, Kumar V. 2006. Introduction to Data Mining. Boston: Pearson Addison Wesley. pengeluaran kabupaten karo pada 2019 yang akan datang adalah 14,22521 triliun Rupiah dan setahun kemudian atau yang belum diketahui adalah 14,72309 triliun Rupiah dan pendugaan jumlah pertumbuhan ekonomi dikabupaten karo pada tahun 2019 yang akan datang sebesar $4,95 \%$. Setahun kemudian atau yang belum diketahui adalah diduga pertumbuhan ekonomi kabupaten karo mencapai 3,49\%.

Masyarakat (DRPM) kementrian riset dan teknologi dengan nomor kontrak T/49/L1.3.1/PT.01.03/2019

Everrit BS, Landau S, Leese M, Stahl D. 2011. Cluster Analysis. Edisi Ke-5. London: King's College.

Juanda B, Junaidi. 2012. Ekonometrika Deret Waktu. Bogor: IPB Press.

Draper N, Smith H. 1992. Analisis Regresi Terapan. Edisi Ke-2. Jakarta (ID): PT Gramedia.

Badan Pusat Statistik (BPS) Kabupaten Karo. 2018. Produk Domestik Regional Broto Kabupaten Karo Menurut Pengeluaran 2013-2017. Katalog 9302020.1211.

Badan Pusat Statistik (BPS) Kabupaten Karo. 2015. Produk Domestik Regional Broto Kabupaten Karo Menurut Pengeluaran 2010-2014. Katalog 9302020.1211.

Badan Pusat Statistik (BPS) Kabupaten Karo. 2018. Pertumbuhan Ekonomi Karo. No.01/07/1211/Thn.IX, Juli. 